\section{Need Analysis in ADDIE Model to Develop Academic Speaking Materials}

\author{
1 Dian Misesani \\ 2 Wendelinus Oscar Janggo \\ 3 Maria Siti Nirmala Wuwur
}

123 Nusa Nipa University, Indonesia

\begin{abstract}
Need analysis has become part of ADDIE model in developing materials for language learning. This research aims at examining the importance of need analysis as the initial focal step prior to the development of materials for Speaking for Academic Purpose. It is also investigating the reliability of ADDIE model prior to developing teaching material, specifically the 'analyze' stage. This research is typically a qualitative descriptive approach which conducted by using survey method. The instruments are students questionnaires and experts questionnaires created in online google form. There are totally 68 higher education students consist of thirty-three (33) seventh semester students and thirty-five (35) of fifth semester students taking the role as the respondents. The experts questionnaires are distributed to six lecturers who have the same interest in materials development and teach English for academic Purposes. The most result showed that 40 and 21 respondents consider 'very important' and 'important' which shows that $90 \%$ of all respondents has similar opinion on the importance of textbook for the course of Speaking for Academic Purpose availability. All of the expert-respondents consider that it is important to develop materials for the course of Speaking for Academic purpose, shown by the dominant answers of 'yes'Thus, by implementing ADDIE model, the researchers are convinced to develop materials for Speaking for Academic Purpose for students of English Education Study Program in Nusa Nipa University.
\end{abstract}

\author{
Keywords \\ need analysis \\ ADDIE model \\ materials development \\ academic speaking
}

\section{Ethical Lingua}

Vol. 7, No. 2, 2020

ISSN 2355-3448 (Print)

ISSN 2540-9190 (Online)

Corresponding Email

Dian Misesani

dianmisesani@gmail.com

Article's History

Submitted 24 October 2020

Revised 26 October 2020

Accepted 28 October 2020

DOI

10.30605/25409190.226

Copyright (๑) 2020

The Author(s)

This article is licensed under CC BY-NC-SA 4.0 License 


\section{Need Analysis in ADDIE Model to Develop Academic Speaking Materials}

Needs analysis has become one of the curcial aspects in English Language Teaching, specifically in the process of material development. The purpose of need analysis is to identify the target language teaching and learners need in order to design effective curriculum (Sönmez, 2019) and/or developing course materials and determining activities for language learning accordingly. English teachers in the higher education should pay more attention to fit the language teaching material and the students' needs. Commonly, the teaching material are developed on the basis of teachers' expectations referring to the learning outcome determined in the curriculum. In other words, the curriculum and syllabus are still the formal aspects to drive the learning outcomes which have to consider the students needs. There are some weaknesses in the English courses at the higher level of language education found by the research similar to Alwasilah (2007): 1) there has been no need analysis counducted to meet students' expectation with the teaching material content, 2) the students' abilities are heteregenous, 3 ) inexperienced teachers in the course with no particular book for the course, 4) no selection and classification based on competencies and students' needs. These weaknesses identify the most problems of the higher students' low English communicative competence associated with the Academic Speaking teaching material content which has not been available.

One of the fundamental principle underlying student-centred learning (Hutchinson \& Waters, 2008; Mubar, 2015) is that teaching/learning process should be responsive by analyzing learners needs (Mubar, 2015; Ndukwe, 2015). Needs analysis which or needs assessment refers to activities involved in gathering information done prior to and as the basis of curriculum or material development to meet students' needs (Hariyadi \& Yanti, 2019). Kaharuddin \& Arafah (2017) have conducted a comprehensive framework for the important steps of need analysis-based materials development for speaking course that can be used as a guideline by designers or English teachers to develop teaching materials. (Lestari, 2014) states that by conducting needs analysis, learning materials content will be appropriately adapted, developed, and implemented. An important point in implementing need analysis for material development is significantly relevan to the current research. That point states that the material content is derived from the needs inventory of the students linguistics needs related to learning abilities and priorities, while information of how to teach is derived from the needs inventory of students learning needs related to learning problems and attitudes.

Similar studies on Need Analysis to develop speaking materials and syllabus for higher education students have been conducted in the past five years. Yana (2016) and Parnawati \& Ulinuha (2019) have conducted a need analysis research to develop speaking skill syllabus and found that students target need was to use speaking skill for their future career. In addition, they want a lot of speaking activities done in pairs or groups. Kaharuddin \& Arafah (2017) has confirmed in their research result that need analysis is crucial to develop welldesigned teaching materials. Al-Maamari (2017) and Menggo et al. (2019) have analysed learners' target needs and learning needs for material development in the academic Englishspeaking course. They suggested that practitioners are to adapt their teaching materials on the basis of need analysis. These researches confirm that need analysis is a good methodology (Dinnel et al., 2010; Syamsuddin \& Afgani, 2019) to developed well-designed syllabus and materials for speaking skill. 
Some studies have investigated the implementation of needs analysis and ADDIE model in developing specifically the language teaching material. Aldoobie (2015) has made a review of ADDIE model in developing instructional design. He states that the analysis stage in ADDIE model is the most important phase in the process in which 'really save huge amount of courses, effort, and time'. This covers four need analyses comprising learners needs analysis, inctructional goal analysis, material development analysis, and learning objectives analysis. Zohoorian (2015) and Aladdin (2016) also state that the focal step in designing materials for language learning is known as Need Analysis. It goes along the notion that need analysis is an initial process finding out the students learning needs by which is later translated to learning objectives that will work as the source of all decisions about the course activities, teaching materials, and evaluations.

Implementing ADDIE model is easy and common in developing teaching material, that this model is recommended by researchers (Cahyadi, 2019) because it helps the scholars to frame how they approached the course redesign process with goals of increased student engagement. This model is also implemented by some researchers to develop materials for speaking course (Kusumawati, 2017; Palupi, 2018) and to improve students' communicative competence (Torre, 2018). Bilah, Gofur, \& Lestari (2017) and Rohmani et al. (2017) state that the advantage of using ADDIE model is that this model is simple and easy to learn as well as a systematic structure which consists of five interrelated components in a systematic and structured. However, it also has a disadvantage specifically in the analysis phase which takes a long time because the course designer is expected to analyze the two components of the first students to divide into two, namely the analysis and performance analysis needs. In this study, the performance analysis related the problems in students speaking performance had been done prior to the need analysis through observation of students' academic speaking evaluation in which many students still had low ability in implementing academic words in their speaking performances.

The research and development aims at bridging the gap between the basic research and surrounding society needs from which its product is useful for education field (Kantum, 2016). In developing the material, it is necessary for lecturers to meet the learners needs and the set CPL or learning outcome to support learners achieving the learning goal (Khwaja, Akhtar, \& Mirza, 2015). This research is a preliminary research with the intention of developing materials on Speaking for Academic Purpose course. It aims at examining the importance of need analysis as the initial focal step prior to the development of materials for Speaking for Academic Purpose. By conducting need analysis distributed to students and experts, it will be strong grounds to develop the teaching material along with the CPL set up by the lecturer. It is also investigating the reliability of ADDIE model prior to developing teaching material, specifically the 'analyze' stage.

\section{Method}

This study is a qualitative descriptive approach which conducted by using survey method. The instruments are students questionnaires and experts questionnaires created in online google form. The data collection technique is by spreading the link of google form via whatsapp application started from July to September 2020. There are totally 68 higher education students consist of thirty-three (33) seventh semester students and thirty-five (35) of fifth semester students taking the role as the respondents. They are active students of English Education Study Program of Teacher Training and Education Faculty of Nusa Nipa University. As Speaking for Academic Purpose course is taught in even (fourth) semesters of 
academic year, the seventh semester students had attended the course in the academic year of 2018/2019. Subsequently, the fifth semester students have attended similar course in the previous academic year of 2019/2020.

The experts questionnaires distributed to six lecturers who have the same interest in materials development and teach English for academic Purposes. These questionnaires comprise 12 questions. In this way, the stage of Need Analysis refers to the stage 'Analyze' in ADDIE development model. In analyzing the data, the researcher uses the interval and conversion of quantitative data with the range of 1-4 for each criterion. The table below shows the questionnaire conversion to score.

Table 1. Questionnaire Conversion to Score

(adapted from Kaharuddin \& Arafah, 2017)

\begin{tabular}{llll}
\hline Importance Level & Frequency Level & Agreement Level & Score \\
\hline Very Important & Always & Strongly Agree & 4 \\
Important & Often & Agree & 3 \\
Fairly Important & Sometimes & Neither Agree nor Disagree & 2 \\
Less Important & Rarely & Disagree & 1 \\
Not Important & Hardly Ever & Strongly Disagree & 0
\end{tabular}

\section{Results}

\section{The Result of Students Need Analysis Questionnaires}

The result of students need analysis questionnaires shows that students need to learn more about academic vocabularies in particular textbook which has not been available before. The students also need to know and practice the language expressions used in academic context such as research presentation, speech in academic forum.

Table 2. Sample of Students Questionnaires and Results from 68 Respondents

\begin{tabular}{|c|c|c|c|c|c|c|}
\hline No & Question & 4 & 3 & 2 & 1 & 0 \\
\hline 1. & $\begin{array}{l}\text { Do you agree that higher education students need } \\
\text { English speaking skill for academic interaction? }\end{array}$ & 40 & 28 & 0 & 0 & 0 \\
\hline 2. & $\begin{array}{l}\text { Is it important to learn academic vocabularies in } \\
\text { the course of Speaking for Academic purpose? }\end{array}$ & 49 & 19 & 0 & 0 & 0 \\
\hline 3. & $\begin{array}{l}\text { Is it important to use particular language } \\
\text { expressions appropriate with academic context? }\end{array}$ & 50 & 18 & 0 & 0 & 0 \\
\hline 4. & $\begin{array}{l}\text { How often do you deliver a research presentation } \\
\text { in the class, in a seminar or conference? }\end{array}$ & 5 & 10 & 0 & 0 & 51 \\
\hline 5. & $\begin{array}{l}\text { Do you ever find any text or book related to } \\
\text { Speaking for Academic purpose in local book } \\
\text { stores? }\end{array}$ & 2 & 3 & 3 & 60 & 0 \\
\hline 6. & $\begin{array}{l}\text { Do you think a textbook will be helpful for the } \\
\text { course of Speaking for Academic purpose? }\end{array}$ & 40 & 21 & 2 & 4 & 1 \\
\hline
\end{tabular}

The data displayed above represent the most crucial questions to analyse learners' need and the importance of particular material for Speaking for Academic course. Question 1 which is 
intended to analyse the learners need of English speaking skill for academic interaction shows that 40 or $58 \%$ of respondents are strongly agree and 28 or $42 \%$ of respondents are agree. Questions 2 and 3 are related to the importance of elements of language to be learnt for the course of Speaking for Academic purpose. These questions has collected nearly similar great scores indicated that academic vocabularies and language expressions in academic context are very important for them to support their academic skills. Question 2 results 49 or $72 \%$ of respondents choosing the option 'very important' and question 3 results 50 or $73 \%$ of respondents choosing similar option. In the option 'important' question 2 results 19 or $28 \%$ and question 3 results $27 \%$ of respondents. Here, the positive answers of learners' needs have been obtained in questions 2 and 3 referring to the importance of material contents in Speaking for Academic purpose, those are academic vocabularies and useful expressions.

The result of question 4 shows that 15 students have the experience of delivering research or academic presentation in English in class, while the others are 'hardly ever' do. Question 5 is aimed at finding information related to the availability of textbook containing academic speaking or any source related to the material for the course. The result of it shows that 50 or $73 \%$ of respondents choose the option 'rarely' which means that such particular book is rarely exist or available in the local store. Question 6 has resulted 40 and 21 respondents consider 'very important' and 'important' which shows that $90 \%$ of all respondents has similar opinion on the importance of textbook for the course of Speaking for Academic Purpose availability.

In addition, the respondents are also given a column or space to write their comments, needs and wants and here are some of them: a) We need the skill of academic speaking specifically in dealing with how to delivering presentation in formal way; b) the book will be the guidance for us that in the future we may need it to improve our skill to present the thesis; c) I need many academic vocabularies, so far, I often use general and limited vocabularies during my presentation or speech in class; d) one day, I want to join a seminar as a presenter so this material will be very useful; e) I want to have an experience as a moderator supported by this material; f) I need confidence to ask questions in a seminar; g) handout is not enough, sometimes I have to search randomly on the internet without any directed material or instructed goal; h) Interactive speaking class will be much interesting than independent speaking activity; i) I need the knowledge of academic speaking in a structured or particular module or maybe book that will support the skill of academic speaking; j) Vocabulary is very important to me because I do not have enough vocabularies to speak up that sometimes I make pauses in the middle of speaking activity.

\section{The Result of Experts Needs Analysis Questionnaires}

The experts needs analysis questionnaires were distributed by sharing the link of google form. There are 6 experts taking part as the respondents of the questionnaire and they all are lecturers with 5-10 years experience in teaching speaking and English for Acdemic Purposes courses.

This expert questionnaire requires 'yes'/'no' answers followed by a comment related to the question in each number. The results show the number of experts answering 'yes' or 'no'. Question 1 shows that 5 respondents have experiences in teaching speaking and in the common columns show that 3 of them teach speaking and Academic English course for more than 5 years until currently while the other 2 teach general speaking course for 4 years. $A$ respondent who answers 'no' is a lecturer majoring in academic writing course. Question 2 
shows that only one respondent find and use a specific book to teach Speaking for Academic Purpose and the comment reveals that this respondent got the book from abroad with high price and complicated process. It is also said that some contents of the book did not meet the students need.

Table 3. Sample of Experts Questionnaire and The Results form 6 Experts

\begin{tabular}{llll}
\hline No & Questions & YES & NO \\
\hline 1. & $\begin{array}{l}\text { Do you teach English for Academic purpose sepecifically } \\
\text { in speaking skill? }\end{array}$ & 1 \\
2. $\quad \begin{array}{l}\text { Is there any relevant book to teach Speaking for Academic } \\
\quad\end{array}$ & 5 & 5 \\
Purpose published? & $\begin{array}{l}\text { Is it important to develop material for the course of } \\
\text { Speaking for Academic purpose? }\end{array}$ & 0 \\
4. $\quad \begin{array}{l}\text { Do you intend to develop the same materials related to } \\
\text { academic speaking? }\end{array}$ & 5 \\
\hline
\end{tabular}

Question 3 result reveals that all of the respondents consider that it is important to develop materials for the course of Speaking for Academic purpose, shown by the dominant answers of 'yes'. Some of their comments state that it s very difficult to find such book related to Speaking for Academic purpose, thus it is important for the lecturer to develop it. One of them suggests that the content should be related to the use of language expressions in academic events such as seminar or conference to prepare the students to present a research ot other academic speeches. This comment is just proper with the final purpose of this research that is to develop materials in preparing students to deliver speech or presentation in academic context. Another one says that there are many books actually, but not all containing specifically to students needs. The lecturer might have to adopt, adapt and compile the material from those book instead. Thus, by implementing ADDIE model, the researchers are convinced to develop materials for Speaking for Academic Purpose for students of English Education Study Program in Nusa Nipa University.

\section{Discussion}

\section{Analyzing Learners' Needs}

As the intial and crucial steps in ADDIE model, the Analyze phase has been done through analyzing the learners needs. The result of questionnaire may also function as to validate the performance gap by relating them to the course learning outcome.The learning outcome or CPL of Speaking for Academic Purpose course are 1) students are able to understand the academic vocabularies, 2) students are able to speak using the language expressions in academic context, 3) students are able to prepare a research presentation and role as a presenter, 4) students are able to take part as a moderator and participate in asking questions. The result of comment columns show that in the previous learning of academic speaking, they were taught of how delivering a speech with free topic without pay attention to academic vocabularies and language expressions. Further, some respondents state that they want to experience a new learning related to Speaking for Academic purpose. Learners' enthusiasm to get out of their current knowledge and skill related to academic speaking is revealed in question 1 in which all the respondents are agree with the notion of improving their academic speaking skill. The result of students need analysis questionnaires 2 shows that students need to learn more about academic vocabularies in particular textbook which has not been 
available before. In addition, they also consider that it is very important to learn the academic language expressions. The positive answers of learners' needs have been obtained in questions 2 and 3 referring to the importance of material contents in Speaking for Academic purpose, those are academic vocabularies and useful expressions.

The result shows, in general, that the learners need to know and practice delivering the language expressions in academic context such as research presentation, speech in academic forum. This is all shown explicitly in the respondents comment columns. Such can be used as the basis for determining the instructional goal that related to context-based learning in which refers to the use of real-life and examples in teaching environments. In context-based learning, the students learn through the actual, practical experience as a presenter, a moderator and/or a participant with academic content such as research presentation or seminar. It is more practical than just merely theoretical learning and teaching by which the goal is to make the students become proficient at Speaking for Academic Purpose.

\section{The Experts Recommendation}

Almost all the experts agree with the idea of developing material for academic speaking. One of them also has similar interest in developing materials for academic speaking. One of them suggests that the researchers should be certain to continue developing this material because it is rarely to find such kind of book proper with the course.

\section{Conclusion}

The results of needs analysis shows that learners need to learn more about academic vocabularies and language expressions in order to deliver presentation in academic context. It is clearly shows from the questionnaires result in which 68 respondents or one hundred percent of respondents agree that they need English speaking skill for academic purpose. On the importance of learning materials to be learned in academic speaking course dealing with the language aspects, all of the respondents agree on the importance of academic vocabularies and language expressions. This means that the content of academic speaking materials should be emphasized more on these two language aspects. Question 4 is asking about students experience in delivering presentation, it shows that they hardly ever do such activity because they are rarely attending seminar or conference. This questionnaire also cover the aim of measuring whether there is any opportunities given to deliver a research presentation provided by the lecturer in class. Thus, this would be a consideration for the course designers, here means the current researchers as well, to design such class activity which give the students opportunities to deliver research articles available in online or offline journals. In this way, the students are also trained and prepared to deliver their own thesis research as the final requirement of higher education.

Further about the availability of a book for academic speaking, questions 5 and 6 show that such book is rarely found in the local book stores and the respondents agree that it will be helpful that this book is available. This is also supported by the results of experts questionnaires which give recommendation to develop the material for academic speaking. Therefore, one of the best solution to improve students academic speaking is providing a textbook containing such materials in the Speaking for Academic purpose.

In developing learning materials, needs analysis is a vital prerequisite to the specification of language learning objectives. The 'Analyze' phase in ADDIE model in material development is 
an important initial stage giving such clear and systematic procedure refers to process of needs analysis. ADDIE is the most simple and used in the area of Research and Development researches to develop valid educational products.

Needs analysis in language education should be involving not only learners, but also analyzing set CPL or learning outcome and other lecturers in the same field of subject. The results would be valid and reliable after which the next step of Design can be continued accordingly. Here, the researcher will design the materials by providing academic vocabularies and academic language expressions integrated in the role as a presenter, a moderator and a participant in a seminar or conference presentation. The students will be trained to speak in academic context by referring to the materials and guidance in this book. By doing this, the students of English department in Nusa Nipa University can be more proficient and confident in presenting their seminar proposal and thesis examination. Good materials provide models, appropriate language use, and practice rather than merely an instrument for language learning.

\section{Acknowledgment}

The researchers are much obliged to The Head of Yayasan Pendidikan Tinggi Nusa Nipa and The Rector of Nusa Nipa University for the funding. Many thanks also to LP2M of Nusa nipa University which is very supportive in providing facilities.

\section{References}

Al-Maamari, F. S. (2017). Informal order, needs analysis, and the EAP curriculum. Qualitative Report, 22(6), 1653-1672.

Aladdin, A. (2016). A Needs Analysis for the Course Materials Design of the Arabic Language Course. International Journal of Social Science and Humanity, 6(6).

Aldoobie, N. (2015). ADDIE Model. American International Journal of Contemporary Research, 5(6), 68-72.

http://www.aijcrnet.com/journals/Vol_5_No_6_December_2015/10.pdf

Alwasilah, C. (2007). Redesigning Indonesian Course in the undergraduate curriculum: The Indonesian case. ASAIHIL Conference.

Bilah, M. S., Gofur, A., \& Lestari, S. R. (2017). Pengembangan ADDIE untuk Matakuliah Anatomi Fisiologi Manusia pada Mahasiswa S1 Pendidikan Biologi Universitas Jember. Seminar Nasional Pendidikan IPA, 2, 508-511.

Cahyadi, R. A. H. (2019). Pengembangan Bahan Ajar Berbasis Addie Model. Halaqa: Islamic Education Journal, 3(1), 35. https://doi.org/10.21070/halaqa.v3i1.2124

Dinnel, P. A., Middaugh, D. P., Schwarck, N. T., Farren, H. M., Haley, R. K., Hoover, R. A., Elphick, J., Tobiason, K., \& Marshall, R. R. (2010). Methods for Conducting an.

Director.

http://www.pubmedcentral.nih.gov/articlerender.fcgi?artid=2965557\&tool=pmcentrez\& rendertype $=$ abstract

Hariyadi, A. \& Yanti, D. R. (2019). The Importance Of Needs Analysis In Materials Development. Jurnal IImiah Profesi Pendidikan (JIPP), 4(2), 94-99. http://jipp.unram.ac.id/index.php/jipp/article/view/88

Hutchinson, T. \& Waters, A. (2008). English for Specific Purposes: A learning-centred approach. Cambridge: Cambridge University Press. 
Kaharuddin, A. \& Arafah, B. (2017). Using Needs Analysis To Develop English Teaching Materials In Initial Speaking Skills For Indonesian College Students. The Turkish Online Journal of Design, Art and Communication. https://doi.org/10.7456/1070ASE/045

Kantum, S. (2016). Hakikat dan prosedur Penelitian Pengembangan. FKIP UNEJ.

Khwaja, L. U., Akhtar, S., \& Mirza, A. (2015). Module III: Curriculum Development, Assesment, and Evaluation. Higher Education Commision.

Lestari, A. R. E. (2014). Analisis Kebutuhan Terhadap Pembelajaran Bahasa Inggris Berbasis Karakter. DEIKSIS, 6(3), 153-164.

https://journal.Ippmunindra.ac.id/index.php/Deiksis/article/view/525

Menggo, S., Suastra, I. M., Budiarsa, M., \& Padmadewi, N. N. (2019). Needs Analysis of Academic-English Speaking Material in Promoting 21 st Century Skills. International Journal of Instruction, 12(2). https://doi.org/10.29333/iji.2019.12247a

Mubar, M. (2015). Developing English Learning Materials for Young Learners Based on Needs Analysis at MTSN Model Makassar. ETERNAL (English, Teaching, Learning and Research Journal), 1(2), 313-330.

Ndukwe, J. I. (2015). Needs Analysis of an English for Academic Purpose (EAP) Programme: English Language Curriculum to the Effectiveness of the Primary School Teacher in Nigeria. IOSR Journal of Research \& Method in Education, 5(4), 45-47. https://doi.org/10.9790/7388-05434547

Parnawati, T. A., \& Ulinuha, A. (2019). English at Higher Education Level: A Need Analysis. Premis: Journal of English Education and Applied Linguistics, 8(2), 214-225.

Rohmani, M., Amin, M., \& Lestari, U. (2017). Analisis Kebutuhan Bahan Ajar Berbasis Penelitian Materi Bioteknologi Bidang Kedokteran Untuk Mahasiswa S1 Pendidikan Biologi Universitas Negeri Malang Berdasarkan Model Pengembangan ADDIE. Pros. Seminar Pend. IPA Pascasarjana UM, 2, 496-501.

Sönmez, H. (2019). An Examination of Needs Analysis Research in the Language Education Process. International Journal of Education and Literacy Studies, 7(1), 8. https://doi.org/10.7575/aiac.ijels.v.7n.1p.8

Syamsuddin, S., \& Afgani, J. A. (2019). A Needs Analysis for the Improvement of the Students' Communicative Competence; A Syllabus design for Speaking 1 Course at English Department Sawerigading University. Eduvelop, 2(2), 109-118. https://doi.org/10.31605/eduvelop.v2i2.247

Torre, L. B. (2018). Using ADDIE Instructional Model Design in the Creation of Learning Module on Purposive Communication Course. International Journal of Engineering Research and Reviews, 6(3), 28-37.

Yana, D. (2016). A Needs Analysis for English Speaking Syllabus Development. AngloSaxon: Jurnal Ilmiah Program Studi Pendidikan Bahasa Inggris, 7(2), 122-130.

Zohoorian, Z. (2015). A Need Analysis Approach: An Investigation of needs in an EAP context. Theory and Practice in Language Studies, 5(1), 58-65. 